\title{
Views of Teachers towards ICT Integration in History
}

\author{
Martin Banda, $\mathrm{PhD}^{1}$, Melody Hamaundu², Beatrice Mumbi Mwansa ${ }^{3}$ \\ ${ }^{1}$ Edenberg university Kitwe \\ ${ }^{2}$ Nalucha primary school Monze \\ ${ }^{3}$ Mulungushi University
}

*Corresponding Author: Martin Banda, PhD, Edenberg university Kitwe

\begin{abstract}
In 2006, Zambiaembarked on the initiative of including ICT in the Education sector, this was so because the government's intention is to transform the country into information and knowledge based society by 2030.Among the National educational goals on ICT in Zambia are that, all teachers will use technology effectively to help students achieve high academic standards, digital content and assist teachers in using technology to access, analyze, and modify student instruction. The Ministry of Communication and Transport realized the importance to modernize the educational delivery systemwiththe use of ICT in order to improve the quality of education at all levels. This is to be done through inclusion of computer skills in teaching and learning process, developing a national ICT curriculum and facilitating internet access in schools and thereafter digitalizing all teaching and learning materials for easy access for teachers and pupils. Therefore, the study investigated teachers' perception towards ICT integration in History subject. Constructivism theory studied by Vygotsky guided the study. Related literature from global, continental and national level were consulted. Mixed research paradigm was employed in the study. The study utilized descriptive research design. The sample size was 52. The study showed that Teachers had negative perceptions in integrating ICT in History subject.
\end{abstract}

\section{BACKGROUND}

In Southern Africa, Zambia is one of the developing countries, which took on the project of developing "Strategic Framework for the Implementation of Education For All (EFA)". The motivation behind Education For All (EFA) policy, according to the document produced by (MOE, 2005), is primarily derived from the Universal Declaration of Human Rights (1994) which stipulate that: "everyone has the right to education". With this thoughtful declaration, Zambia's education policy is still encountering challenges in information sharing and its flow within the system, poor quality of learning, fewer classroom places and learning hours, lack of equipment and laboratory infrastructure as well as insufficient textbooks as noted by MOE (2005).

Therefore, the incorporation of (ICT) can help to alleviate these problems in education system in Zambia in order to provide quality education and help the Zambian government to meet its commitment of achieving the "Education For All" initiative as noted by Mwale, (2011). Although the ministry of education's Strategic plan 2003-2007' states and affirm the importance of ICT in improving the quality and accessibility of education. It is regretted that there is no policy articulated in the Zambian 2013 revised curriculum to guide ICT use within the education sector. It is therefore critically vital that the current Curriculum should guide the use of ICT in the education sector as a current trend embraced by the world as (MOE, 2003) put it.

ICT policy aims at integrating ICT in the education system. The promotion of ICT integration has also been in the teaching of History. Since the introduction of ICT policy in education, concerns have been raised regarding teachers' awareness and proper usage of ICT.

\section{THEORETICAL FRAMEWORK}

The study was guided by the constructivism theory of learning by Vygotsky who indicates that learners construct and build their own knowledge of the world around them through life experiences. The school curriculum in particular, changed from previously observing positivist epistemology (behaviorist) learning theory to constructivist epistemology and learner centered education (Kalpana, 2014). The shift also resulted in the teacher education curriculum adopting a constructivist epistemology paradigm shift in secondary schools which is noted in learner centered learning. 
Attention to this learning theory resulted in the shift from instructional approaches such as behaviorism, cognitivism and humanism to learner centered approach promoted by constructivism, which promotes active learning through knowledge construction (Nawaz, 2012). The critical issue of including learning theory in ICT application design for teaching and learning has been reported in literature (Slavin, 2006). The literature has consistently pointed out that constructivist learning theory is an appropriate match for ICT application design in teaching and learning process.

From the constructivist learning perspective learning is contextualized. Teachers in education have to design learning activities, which require learners to interpret, argue, practice and transfer ideas to other situations. Kharade and Thakkar (2012) argues that it is from this that learners develop cognitively and construct, create and acquire knowledge. Nawaz (2012) point out that, in the learning paradigm education institutions and teachers should create powerful learning environments. It seems obviously that these learning environments should provide learners with opportunities to reflect on what they are learning so that they understand it and be able to apply the constructed knowledge in a new context or environment. Therefore, the use of ICT in teaching and learning should be aligned with constructivist learning principles to improve the quality of teaching and learning.

According to Kharade and Thakkar (2012), constructivism entails that the active learners construct their own knowledge while the teacher facilitates the learning process. The integration of ICT in teaching of History allows learners to experience reality as they do not forget easily what they have seen hence, making an experiential reality to learners.

\subsection{Global studies about teachers' perceptions towards ICT.}

In India, a study by Padmarathi (2013) in Puducherry, where he surveyed secondary school teachers' perceptions, competence and use of computer. The aim of the study was to bring out secondary school teachers' perceptions and competence in relation to action use of computers in the classroom teaching. The findings from the survey showed that teachers in India had a favorable perception towards the use of ICT. Teachers did not have any major challenge and enjoyed using ICT in teaching. The study also by Rajaseka (2007) on computer knowledge and attitude towards computer teachers of 670 high school secondary teachers in Guddatore District of Tamilandu revealed that $60.4 \%$ of the teachers had relatively positive attitude towards computers. In another study by Narasimhan (2012) on the attitude of secondary school teachers of English in Srikakulum District of Andhra Pradesh in India equally showed positive attitude of teachers towards ICT. The studies revealed that they were in support of using ICT in the teaching of English. These studies did not pay attention to teaching of history, therefore, there was need to embark on an investigation to teachers' perceptions towards ICT integration in Zambian secondary schools.

Shamsudirin (2012), studied on the integration of ICT in teaching and learning in Indian secondary schools. The study revealed that ICT is an enabler in education and provide a strong rationale why ICT need to be integrated into teaching and learning process. An array of new technologies such as radios, slide films, projectors, overhead projectors have huge potential in improving education. Newhouse (2007) also indicated that integrating ICT in teaching and learning is useful to build knowledge as a result of active learning and authentic assessment, motivational and challenging engagement, increasing learner independence, tools for higher order thinking, collaborative and cooperative learning and tailoring learning to learners.

Harrison (2002) conducted a research in three primary and three secondary schools in Malaysia, which focused on innovative pedagogical practices involving ICT. He concluded that benefits of ICT will be gained when confident teachers are willing to explore new opportunities for changing their classroom practices by the use of ICT. (Rodgers, 2003) notes the use of ICT will not only enhance learning environment but also prepare the next generation for their future lives and careers. The findings revealed that lack of internet at the school does not augur well for students in this information era. The argument is that internet has the role for the successful integration of ICT in education as well as enables teachers to transform instruction from teacher centered to student centered. Thus, students may interact with their peers and use it for their own learning needs, but in Zambia, little was known about the way teachers view the use of ICT in teaching and learning process of History. The study showed that respondents had fairly good perceptions towards ICT and suggested by Cop and Ward (2002) in their work integrating learning technology into classroom. The results showed that ICT will bring them and their students advantages in that ICT makes their teaching effective, possible to attend to the varying needs of students, motivate their students, promote collaboration among 
students, enhance students' interests and increase teachers' productivity. This study provided a base for the current study to find out if History teachers have the same views.

A study carried out by Harrison and Rainer (2000) on ICT integration in teaching and learning process among teachers teaching large Universities in the United States of America found out that many of the teachers were not skilled in computer use and therefore had negative perception about it. Another study by Albirini, (2004) about ICT integration in teaching and learning in Syrian high schools indicated that teachers had a positive attitude towards integration of ICT in teaching and learning process. The $78 \%$ of teachers in high schools in Syria were interested in developing their ICT skills and knowledge.

\subsubsection{African studies.}

Jonathan (2011) carried out a study of history teachers' perceptions of ICT in promoting teaching and learning in Ghana. The integration of ICT into history is much more complicated than providing computers with internet connection. The integration of technology takes time to learn about innovation and time to be adequately prepared to use it. Based on the findings of the study, it was concluded that History teachers hold positive perceptions towards ICT integration in education and have strong desire for integration of ICT into teaching of history, which was not known in Zambian secondary schools. The History teacher needs to adopt, develop and support practices for students and encourage teaching and learning activities. It should be linked to the development of lifelong learning and professional practices that enable history teachers to be acquainted with ICT developments, new knowledge and research on teaching and learning.

Malaika (2018) carried out a research on the teachers' perceptions on the use of ICT in teaching and learning in Namibian primary schools. The findings indicated the ICT usage in schools improved teaching and learning. Teachers and pupils benefit in education as ICT tools are associated with providing easy teaching and learning. Teaching with ICT facilities is more significant than that of ordinary teaching method as (Abudu\&Banday, 2012) notes.

In Kenya, Kaptalan (2010) investigated the accessibility and utilization of ICT among secondary school teachers and revealed that teachers had a positive attitude towards ICT and appreciated its usage in teaching and learning. The findings were also in agreement with Lau and Sims (2008) in Malaysia who made a number of interesting observations in the use of ICT in education. In Malaysia, $75 \%$ of teachers said they use ICT for teaching and $71 \%$ considered their competences to be excellent and good in word processing. Teachers agreed that ICT use made their work effective by $80 \%$ and $86 \%$ of the respondents showed that they would like to integrate ICT in their teaching but they had limited knowledge to make full use of ICT. There was therefore a need to explore teachers' perceptions towards usage of ICT in teaching and learning in Zambia.

\subsubsection{Zambian studies}

Bahufite (2015) carried out a study on the Constructivist methods of teaching and learning using ICT in Zambian secondary schools. The purpose of the study was to find out the various ways the secondary schools get the learner involved in the teaching and learning process using ICT mediated methods in all the subjects. The usage of ICT per subject were illustrated by percentages as follows, ICT $100 \%$, English $36.11 \%$, Chemistry $34.72 \%$, Biology and integrated science had $19.44 \%$, Geography $11.11 \%$, mathematics $8.33 \%$, R.E $5.56 \%$ and History had the least percentage of $1.39 \%$. The scored percentage for History gave a base for the study to be undertaken.

Further, Lufugulo (2015) carried out a study on primary school teachers' attitudes towards ICT integration in social studies. The purpose of the study was to find out primary school teachers attitudes towards integration of ICT in teaching social studies. The study showed that knowledge on the use of available ICT in schools is crucial for the successful delivery of lesson. The findings were in line with Rogers (2003:21) who states that, 'innovation decision process starts with the knowledge state. An individual learns about the existence of an innovation and seeks information about the innovation.' Therefore, understanding ICT is crucial because it determines the teachers' attitudes towards it. Bectas (2004) indicates that teachers' attitudes towards computers have significant implications for their behavior in the use of computers for teaching. Additionally, teachers' knowledge and attitudes function as major predictors of the use of ICT in process of combining ICT with education. Hence, their perceptions towards using ICT knowledge besides their talents and desire will be crucial point affecting the results of application. The findings of the research showed that Primary 
school teachers had a positive attitude towards ICT usage in the teaching and learning process. Teachers integrated ICT in the process of teaching social studies.

The study by Mulima (2014) in Kabwe on the teachers and learners' perceptions on the role of ICT in R.E showed that teachers and learners had a positive perceptions of ICT. The study further showed that learners were able to understand Religious Education lesson better when ICT were used. The ICT made it easier for learners to grasp and understand the concept in detail. Participation levels were raised in learning Religious Education with the application of ICT. However, the positive perceptions on application of ICT in schools came from one subject teaching area and only in three schools. These studies did not pay attention to teaching of history hence the need for the investigation on the perceptions of History teachers on the use of ICT in teaching and learning.

Moono (2017) conducted a study on teachers and pupil perceptions on ICT as examinable curriculum subject. The study showed that both teachers and pupils had positive perceptions towards ICT as an examinable subject in Mazabuka District. The study established that teachers and pupils found ICT to be an easy, interesting and a very useful practical subject in society nowadays than in the past. This can help improve and develop the quality of education by providing curricular support in perceived difficult subject areas like History.

\section{METHOLODOGY}

The mixed research paradigm (qualitative and quantitative) was preferred for the study in order for the researcher to have an in-depth understanding of how teachers interpreted, regarded and understood the integration of ICT in History subject. The study employed descriptive research design. The sample population comprised of all head of section for History andteachers for History and ICT of four (4) selected secondary school and the sample size was 52 .

The questionnaire and semi-interview guide was used as research instrument for collecting data. Quantitative data was analyzed using excel software2016 version and qualitative data was thematically analyzed.

\section{RESEARCH FINDINGS}

\section{Availabilities of ICT in schools.}

In order to get the constructive perceptions of teachers towards the use of ICT in history subject, it was vital to find out the types of ICT that were found in schools. The findings pertaining to the availability of ICT in schools are presented in the figure below.

\section{Types of ICT available in schools}

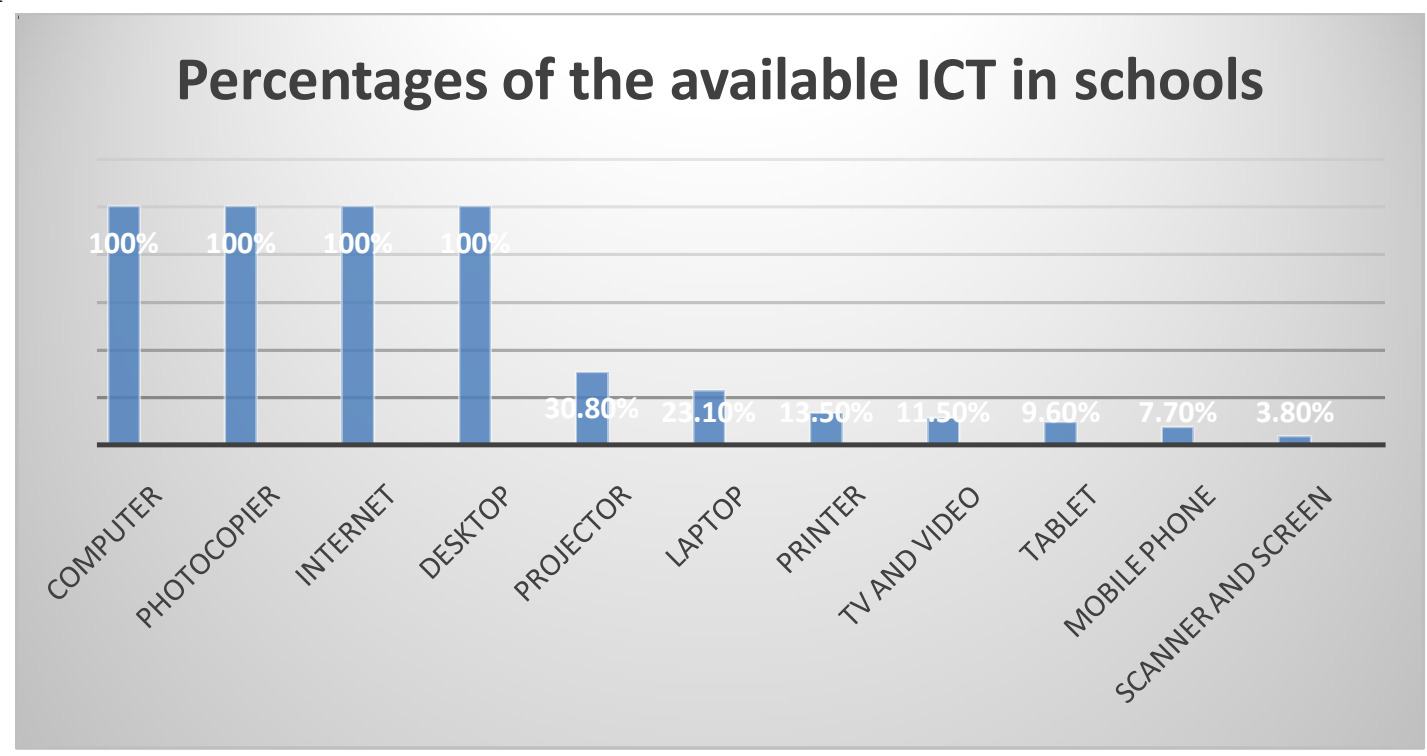

Source: Field work 2019

The study results in figure shows that all the schools visited possess computers, photocopier, internet, desktops as confirmed by all the 52 respondents. The other facilities available includes Projector as confirmed by 16 teachers out of 52 teachers (30.8\%), Laptops, TV and Videos, Printer, Tablet and Mobile phones, Scanner Screen as respectively confirmed by 12 (23.1\%), 7 (13.5\%), 6 (11.5\%), 5 
(9.6\%), $4(7.7 \%), 2(3.8 \%)$. The other ICT facilities available in schools as confirmed by the ICT teacher were whiteboard, speaker, microphones, cameras, webcams and calculators.

\section{Use of ICT available in schools in teaching of History}

Concerning the use of available ICT in the teaching of history, the HOS, teachers for History and teachers for ICT's responses are presented below.

Percentages and frequency distribution of respondents on the usage of ICT in teaching History. $(\mathbf{n}=52)$

\begin{tabular}{|c|c|c|c|}
\hline & Teachers for History & $\begin{array}{l}\text { Head of section for } \\
\text { History }\end{array}$ & Teachers for ICT \\
\hline Responses & $\%$ & $\mathrm{f} \quad \%$ & $\%$ \\
\hline YES & 25 & 50 & 12.5 \\
\hline NO & 24 & 50 & 87.5 \\
\hline Total & 100 & 100 & 100 \\
\hline
\end{tabular}

Source: Field work 2019

Table above depicts the low usage of ICT facilities in schools by teachers. Some schools are well equipped with these facilities but do not have enough capacity to use them because of different reasons. However, the situation was not the same in all the schools, some schools used the ICT in teaching as indicated by $8(25 \%)$ of teacher for History $2(50 \%)$ of the Head of section and $2(12.5 \%)$ of teacher for ICT.

\section{Conversance of teachers with ICT facilities.(n=52)}

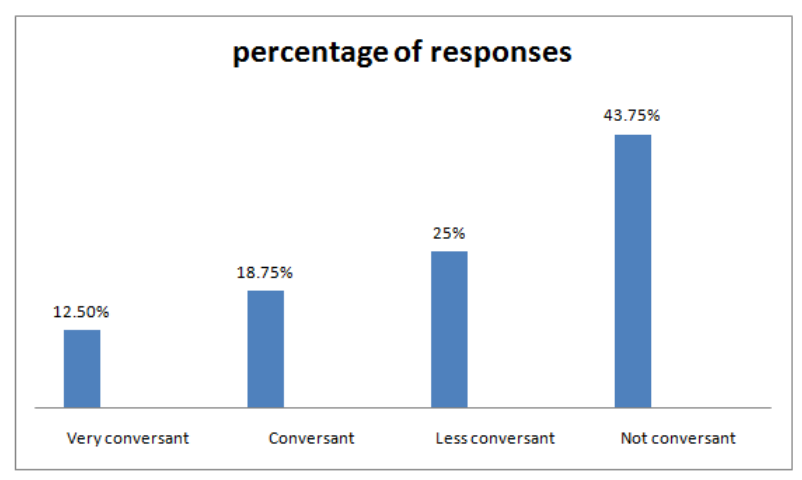

Source: Field work 2019

The results on the graph indicates that the majority of the respondents in the sampled schools said that they were not using ICT facilities in teaching because they were not conversant as presented by $43.75 \%$. This could be one of the reason to why teachers were not integrating ICT in the teaching process are presented in table.

However, not all respondents were not conversant, others were very conversant as presented by $12.5 \%$, conversant by $18.75 \%$ and less conversant with $25 \%$.

Training of teachers in ICT integration in the teaching and learning. $(n=52)$

To find out about the teachers' perceptions towards ICT integration, the question seeking to know whether the teachers were trained in the ICT mediated method was asked and the responses are presented in the following figure. The following figures depicts the training of teachers in the ICT mediated pedagogy.

\section{Trained teachers for History in ICT}

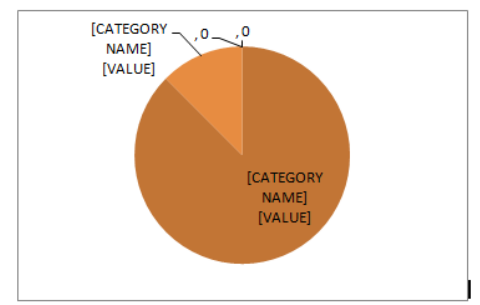


Figure shows that $28(87.5 \%)$ were not trained in ICT mediated methods and only $4(12.5 \%)$ of the teachers in the visited schools during field work trained in related education courses. Besides, the $12.5 \%$ were trained in basic skills in ICT.

How teachers' perceived ICT integration in teaching History subject? $(\mathbf{n}=52)$

\begin{tabular}{|l|l|}
\hline RESPONSE & FREQUENCY \\
\hline Promote education efficiency & 6 \\
Arouse interest & 7 \\
Active learning & 2 \\
Laziness in pupils and teachers & 5 \\
Cause learners to misbehave & 6 \\
Wastes time & 9 \\
Difficult to incorporate ICT & 7 \\
Short time allocated to incorporate ICT & \\
Teachers fail to perform without ICT & 3 \\
\hline TOTAL & $\mathbf{5 2}$ \\
\hline
\end{tabular}

\section{Source: Field Work, 2019}

The findings of the study revealed that teachers had a negative attitude towards ICT integration in the education system. The frequency of 32 out of 52 indicated that the integration of ICT waste time, cause learners to misbehave, promote laziness in learners and teachers, it is difficult to incorporate ICT in teaching and learning process, makes teachers fail to perform without ICT facilities and time is limited to incorporate ICT in teaching and learning process.

\section{Teachers do not perform well using ICT}

According to the respondents, the incorporation of ICT has led teachers to depend more on ICT as a result they do not perform well because the information on the web or internet are mostly written on personal views. Furthermore, respondents argued that History subject need to be studied carefully through primary and secondary verified and approved sources in order to get it authencity and reliability. The findings are in line with Sandhortz (2016), whose study findings were that, some teachers in India viewed the use of ICT in searching for information not reliable especially to teachers and learners who does not know how to differentiate between opinion and facts.

\section{ICT makes learners lazy}

Some respondents argued that, learners become lazy to work on class activities like Exercise and being in classrooms because they can easily get the study material from the web. They argued that some website pupils encounter as they research on internet changes their behavior to become more irresponsible. For instance, a teacher gives a homework to the learners, they may not understand the topic if they never attend that class. Further, the teachers for History observed that the education content for History subject is guided by a curriculum, so if learners get any information on the websites they can be misled and end up writing unnecessary content in the examination.

\section{ICT makes learners to misbehave}

The technological reliability is very important and yet the learners could respond negatively to the resource, both to teaching and technology. ICT may lead the learners into cheating by cutting and pasting when given assignment. Through this type of behavior, reliability of the learners will be affected. Besides, learners may not only search for academic work on web but access the internet for other social media like Facebook, Yahoo, Twitter and WhatsApp as well as pornography while having a lesson, Learners may not pay more attention to what is taught hence, their attitude may change and become rebellious.

\section{ICT integration waste time in the classroom}

Some teachers perceived the use of ICT as a wastage of class time as most teachers who integrate ICT in teaching spend most of the class time on the power point presentation and cannot give learners time to express themselves leaving no room to attend to individual learners and giving class activities. The findings are similar to (Becta's study 2004) found that the problem of lack of time exists for teachers in many aspects of their work affects their ability to complete tasks, with some of the 
participant teachers specifically stating which aspects of ICT require more time. These include the time needed to locate internet advice, prepare lessons, explore and practices using the technology and deal with technological problems during teaching.

\section{Time allocation for history subject is short to use ICT}

In line with the above findings, teachers viewed 40 minutes allocated for history as too short if ICT was to be incorporated in teaching topics like Adolf Hitler, Benito Mussolini whose content is too bulk. Respondents preferred traditional method than the use of ICT in spite the global world embracing it in education.

\section{ICT integration is difficult to incorporate.}

The most frequented result on teachers' perceptions was the problem of failure to use computers without training. Most respondents indicated that they were unable to use ICT because they lack training in ICT mediated methodologies and this was themajor hindrance of ICT usage in the study area. Teacherslacked training on how to use the facilities confidently.

\section{CONCLUSION}

The study found out that teachers perceived ICT integration in the education sector negatively. The study revealed that most teachers in the study area were not using the available ICT facilities because of lack of training in ICT mediated methodologies and this could have influenced the way they interpreted, regarded and understood the integration of ICT in History subject. And this was triggered by the absence of ICT policy in the Zambian 2013 revised curriculum to guide the use of ICT in the Education sector to indicate its importance. The government of the republic of Zambia should consider training the teachers for them to realize the importance of ICT in the Education system.

\section{REFERENCES}

[1] Albrini. A. (2006). Teachers' attitudes towards Information and communication technologies: The case of Syrian EFL teachers' computers \& Education 47,373-398.

[2] Becta (2004). The impact of information and communication technologies on learning and attainment full report.13 March 2003.

[3] Kalpana, T. (2014). A constructivism Perspective on Teaching and Learning: A Conceptual framework. International Research Journal of Social sciences. ISSN 2319-3565. Vol.3(1), 27-29. January (2014) int. Res.Social science. Available online at; www.Isca.in.me.

[4] Kharade, K \& Thakkar, R. (2012). Promoting ICT enhanced Constructivist Technology practices among pre-service Teachers: A case study: International Journal of Scientific and research publication. Vol.2.Issue, January 2012 ISSN 2250-3153.

[5] Kombo, D, and Tromp, D, L, A. (2006). Proposal and Thesis writing. Nairobi: Pauline Publication Africa.

[6] Ministry of Education (1996). Educating our future: Policy on Education: Lusaka Zambia.

[7] Ministry of Communication and Transport, (2006). National information and communication Technology policy. Lusaka. Available at http://unpan 1.un.org/intradoc/groups/documents/unpan/unpan032690 .pdf.Retrieved on 24/10/19

[8] Ministry of Education, Science, Vocational Training and Early education, (2012). The Zambian Educational curriculum framework. Lusaka. CDC.

[9] Mwale, M, Chilala and Kumar, S. (2011). African leadership in ICT: Assessment of Environmental, institutional and indication capacity needs for the knowledge society.

Citation: Martin Banda, PhD, et.al, "Views of Teachers towards ICT Integration in History" International Journal of Humanities Social Sciences and Education (IJHSSE), vol 7, no. 6, 2020, pp. 116-122. doi: http://dx.doi.org/10.20431/2349-0381.0706013.

Copyright: () 2020 Authors. This is an open-access article distributed under the terms of the Creative Commons Attribution License, which permits unrestricted use, distribution, and reproduction in any medium, provided the original author and source are credited. 